\title{
PENGARUH HARGA, TESTIMONIAL DAN WORD OF MOUTH (WOM) TERHADAP KETERTARIKAN KONSUMEN PADA PRODUK MS GLOW DI KABUPATEN LUMAJANG
}

\author{
Hesti Irnanta \\ Program Studi Manajemen, STIE Widya Gama Lumajang
}

\begin{abstract}
The purpose of this study was to determine and analyze the effect of the role of price, testimonials and word of mouth (WOM) on consumer interest in MS GLOW products. This type of research uses descriptive quantitative. The data used are primary data using a questionnaire. The research sample was respondents, amounting to 152 people. The dependent variable is consumer interest with 5 indicators. And the independent variables in this study are price, testimonials, and word of mouth (WOM). The data analysis used was multiple linear regression analysis. The results showed that the variable price and word of mouth (WOM) had a significant effect on consumer interest, while testimonials had no effect on consumer interest in MS GLOW products.
\end{abstract}

Keywords: price, testimonials, word of mouth (WOM).

\section{ABSTRAK (Times New Roman 11, ditebalkan, miring)}

Tujuan dari penelitian ini adalah untuk mengetahui dan menganalisis pengaruh peran harga, testimonial dan word of mouth (WOM) terhadap ketertarikan konsumen pada produk MS GLOW. Jenis penelitian menggunakan deskriptif kuantitatif. Data yang digunakan adalah data primer menggunakan kuisioner. Sampel penelitian merupakan responden yang berjumlah 152 orang. Variabel dependen adalah ketertarikan konsumen dengan 5 indikator. Dan variabel independen dalam penelitian ini adalah harga, testimonial, dan word of mouth (WOM). Analisis data yang digunakan menggunakan analisis regresi linier berganda. Hasil penelitian menunjukkan bahwa variabel harga dan word of mouth (WOM) berpengaruh signifikan terhadap ketertarikan konsumen, sedangkan testimonial tidak berpengaruh terhadap ketertarikan konsumen pada produk MS GLOW.

Kata-kata Kunci: harga, testimonial, word of mouth (WOM).

Korespondensi: Hesti Irnanta, S.AB., M.AB. STIE Widya Gama Lumajang. Jl. Gatot Subroto Nomor 4 Lumajang 67352. Email: irnantahesti25@gmail.com. 


\section{PENDAHULUAN}

Ketertarikan konsumen adalah suatu fokus untuk hal yang didahulukan atau prioritas. Ketertarikan merupakan faktor pribadi yang mempengaruhi proses pengambilan keputusan pada diri konsumen (Lalitamanik, Apriatni, \& Dewi, 2014). Hasil yang didapat dalam penggunaan suatu produk yang tidak sesuai dapat memberikan dampak negatif bagi konsumen. Maka dari itu, perusahaan harus memiliki upaya untuk mempertahankan konsumen. Ketertarikan konsumen dapat dilihat ketika konsumen merasa ingin mencoba menggunakan atau membeli produk tersebut.

Beberapa penentu ketertarikan konsumen terhadap suatu produk yang dapat dijadikan solusi antara lain adalah harga, testimonial dan word of mouth. Harga adalah segala bentuk biaya moneter yang dikeluarkan oleh konsumen guna mendapatkan, memiliki, dan menggunakan sejumlah barang beserta pelayanan dari suatu produk tersebut (Runtunuwu, Oroh, \& Taroreh, 2014). Harga menjadi peran penentu dalam pembelian konsumen. Namun hal tersebut berlaku hanya untuk kelompok-kelompok tertentu dan beberapa jenis produk komoditas. Penetapan harga dikatakan perlu karena memberikan serangkaian kekuatan-kekuatan lingkungan dan persaingan yang dapat dikatakan sangat rumit. Harga yang ditetapkan oleh tiap perusahaan menyesuaikan tiap produk agar dapat mencerminkan setiap perubahan biaya, permintaan dan perhitungan keadaan pembeli serta situasi yang berubah-ubah (Nst \& Yasin, 2014). Sesuai dengan teori permintaan dalam harga, dampak yang akan terjadi adalah meningkatnya pembelian apabila harga yang ditetapkan semakin rendah, sebaliknya apabila harga yang ditetapkan semakin tinggi maka akan mempengaruhi turunnya pembelian.

Testimonial juga menjadi pengaruh yang kuat dalam pembelian secara online. Testimonial sendiri memiliki pengaruh yang amat sangat penting karena dapat menumbuhkan kepercayaan konsumen. Testimonial merupakan bukti ungkapan pelanggan atau konsumen terhadap suatu produk atau jasa serta pelayanan yang telah digunakan atau dirasakan (Syifa, Heryanto, \& Rochani, 2018). Testimonial merupakan 
salah satu cara yang digunakan untuk mempublikasikan informasi di media sosial dimana informasi tersebut harus memihak kepada orang banyak, bukan hanya pada kepentingan pribadi (Kuncoro \& A.W., 2019). Testimonial yang dapat menarik perhatian konsumen adalah testimonial yang bernilai persuasif. Maksud dari persuasif sendiri adalah testimonial yang disajikan bukan hanya konsep teks. Konsep visual baik foto maupun video sebagai pelengkap ulasan agar lebil detail guna lebih menarik banyak konsumen (bisnisbisnis.id).

Selain penggunaan testimonial, cara lain yang dapat digunakan pendukung dalam menarik konsumen adalah dengan cara word of mouth (informasi dari mulut ke mulut). Menurut Rachman dan Cahaya (2015) word of mouth merupakan berbagai tindakan pemberitahuan tentang pengalaman positif ataupun negatif yang dikomunikasikan seseorang setelah masa pembelian, merasakan manfaat atau telah menggunakan suatu produk atau jasa (Finanda \& Wiwaha, 2017). Tindakan word of mouth ini seringkali membawa konsumen baru terbawa pengaruh oleh seseorang yang menyebarkan informasi. Kebanyakan konsumen lebih mempercayai word of mouth karena dinilai efektif dalam memberikan keputusan dan lebih dapat dipercaya karena informasi yang didapat diperoleh dari orang-orang terdekat (Syifa, dkk., 2018). Informasi yang didapat melalui word of mouth biasanya pada lingkup terdekat seperti keluarga dan teman sejawat. Namun kerap saja terjadi perubahan keyakinan dimana seorang konsumen baru tidak lagi tertarik dengan informasi produk tersebut dikarenakan mendapatkan informasi buruk dari pihak lain sehingga mengurungkan niatan konsumen untuk membeli produk tersebut (turboly.com).

\section{LITERATURE REVIEW}

Harga merupakan segala bentuk biaya yang dikeluarkan oleh konsumen untuk mendapatkan barang atau jasa atau juga dapat dikatakan sebagai penentu nilai suatu produk dalam pikiran konsumen (Runtunuwu et al., 2014). Adapun beberapa indikator harga yang digunakan dalam penelitian ini menurut Stanton (1998) dalam Saputra (2017) yakni sebagai berikut: 1) Keterjangkauan harga. Konsumen bisa menjangkau 
harga yang telah ditetapkan konsumen dari harga termurah hingga termahal. 2) Kesesuaian harga dengan kualitas produk. Harga seringkali dijadikan sebagai indikator kualitas bagi konsumen. Orang memilih barang dengan harga yang lebih tinggi diantara barang karena mereka melihat perbedaan dari kualitas. 3) Daya saing harga. Seringkali konsumen membandingkan harga suatu produk dengan produk lainnya. Dalam hal ini mahal murahnya produk menjadi pertimbangan konsumen dalam proses pembelian. 4) Kesesuaian harga dengan kualitas manfaat. Kesesuaian harga dengan manfaat menjadi pertimbangan konsumen dalam membeli suatu produk artinya nilai manfaat dari suatu produk harus sebanding dengan harga yang ditetapkan oleh perusahaan.

Testimonial merupakan cara yang digunakan unutk membangun kepercayaan, dimana informasi yang dipublikasikan pada media sosial harus menjangkau dan memihak kepada banyak orang, bukan hanya pada kepentingan pribadi saja Andrew Griffith (2011:153) dalam Syifa et al (2018). Adapun tolak ukur yang digunakan untuk mengukur testimonial Mon Lee dan Carla Jhonson (2007:186) dalam Ningrum \& Tresnati (2017), antara lain: 1) Daya tarik. Meliputi adanya kesamaan yang dimiliki, kesamaan karakteristik, kepribadian dan gaya hidup seseorang yang ditampilkan dalam bentuk iklan dan lain sebagainya. Serta pada obyek yang digunakan seperti yang sering dijumpai pada sehari-hari. 2) Kredibilitas. Merupakan perluasan di mana pembaca atau penerima dapat mempercayai sebuah ulasan yang diberikan oleh pembeli sebelumnya. 3) Spontanitas. Dimana sebuah testimoni dibuat berdasarkan pengalaman yang dirasakan oleh pembuat, bukan berdasarkan skrip yang sudah direkayasa sebelumnya.

Word of mouth merupakan pesan mengenai sebuah barang maupun jasa perusahaan dalam bentuk ulasan tentang manfaat produk, kepuasan dalam pelayanan serta hal lain yang dirasakan oleh konsumen kepada konsumen baru Andreas (2012) dalam Priansa (2017:338). Word of mouth dapat diukur yang dapat menakar persebarannya (Priansa, 2017:348-349), yaitu: 1) Talkers. Penyebar informasi adalah orang yang telah menggunakan produk tersebut terlebih dahulu. Konsumen biasanya memakai produk 
kareana anjuran dari talkers, atau yang biasa disebut dengan referral yakni pihak yang memberikan rekomendasi tentang suatu produk. 2) Topics. Pesan yang terkandung dalam word of mouth menjadi substansi pembicaraan. 3) Tools. Suatu alat yang digunakan unutk membantu agar pesan tersebut dapat berjalan dan tersebar sehingga membuat orang yang menerima pesan tersebut mudah membicarakan dan menularkan produk pada temannya.

\section{METODE}

Jenis peneitian ini menggunakan penelitian kuantitatif. Teknik pengambilan sampel dalam penelitian ini menggunakan teknik purposive sampling, yaitu dimana sampel yang ditarik dari populasi berdasarkan beberapa kriteria yang dibuat oleh peneliti, dengan kriteria dalam penelitian ini adalah sebagai berikut: 1) Konsumen yang pernah membeli produk MS GLOW. 2) Konsumen yang memiliki rentang usia 17 - 40 tahun. Jumlah sampel yang dapat diambil sesuai dengan jumlah populasi $(\mathrm{N})$ yang berjumlah 250 adalah sebanyak 152 sampel (S).

\section{HASIL DAN PEMBAHASAN}

Hasil yang didapatkan pada pengujian hipotesis menunjukkan bahwa pengaruh testimonial tidak berpengaruh signifikan terhadap ketertarikan konsumen pada produk MS GLOW di Kabupaten Lumajang. Hasil ini mengidentifikasi bahwa testimonial meningkat atau menurun tidak mempengaruhi ketertarikan konsumen. Sebagai penjelasan fenomena tentang mengapa variabel testimonial tidak memiliki pengaruh yang signifikan terhadap ketertarikan konsumen, karena bagi konsumen testimonial tidak begitu menjadi hal utama dalam mempengaruhi ketertarikan dalam diri konsumen karena dirasa meskipun tanpa adanya testimonial konsumen dapat membuktikannya sendiri tanpa harus melihat testimonial dari orang lain, dan konsumen juga lebih memperhatikan faktor lain seperti halnya kualitas yang ditawarkan serta kebutuhan yang dibutuhkan setiap konsumen relatif bermacam- 
macam. Testimonial merupakan suatu rekomendasi dalam bentuk komentar yang disebarkan pelanggan berdasarkan pengalamannya dan memiliki pengaruh yang sangat kuat guna pengambilan keputusan yang akan dilakukan oleh pihak lain Lovelock (2011:73) dalam Ardiansyah, Widiana, \& Pudjowati (2014).

Setelah melakukan pengujian, hasil menujukkan bahwa word of mouth berpengaruh signifikan terhadap ketertarikan konsumen pada produk MS GLOW di Kabupaten Lumajang. Hasil penelitian menunjukkan bahwa sebagian besar pembeli produk MS GLOW di Kabupaten Lumajang memberikan tanggapan setuju terhadap variabel word of mouth.

Adapun instrumen pertama yang dominan mendapatkan pernyataan setuju dari konsumen yakni penyampaian informasi dari seseorang yang pernah menggunakan produk MS GLOW lebih memudahkan dalam memberikan informasi kepada kerabat atau keluarga. Dalam artian, penyampaian dari orang yang pernah menggunakan produk MS GLOW akan lebih fleksibel dalam merekomendasikan kepada orang lain karena telah merasakan sendiri manfaat suatu produk sehingga mampu menguasai pertanyaan yang akan diberikan oleh calon konsumen.

\section{KESIMPULAN}

Berdasarkan hasil analisis dan pembahasan tentang menilai ketertarikan konsumen melalui harga, testimonial dan word of mouth pada produk MS GLOW di Kabupaten Lumajang, maka dapat ditarik kesimpulan antara lain sebagai berikut:

a. Harga berpengaruh signifikan terhadap ketertarikan konsumen pada produk MS GLOW di Kabupaten Lumajang. Hasil ini memberikan dukungan terhadap pengajuan hipotesis yang menyatakan harga berpengaruh signifikan terhadap ketertarikan konsumen. Artinya, hasil pada penelitian ini membuktikan adanya pengaruh yang signifikan dari variabel harga terhadap ketertatikan konsumen pada produk MS GLOW di Kabupaten Lumajang.

b. Testimonial tidak berpengaruh signifikan terhadap ketertarikan konsumen pada produk MS GLOW di Kabupaten Lumajang. Hasil ini tidak memberikan dukungan 


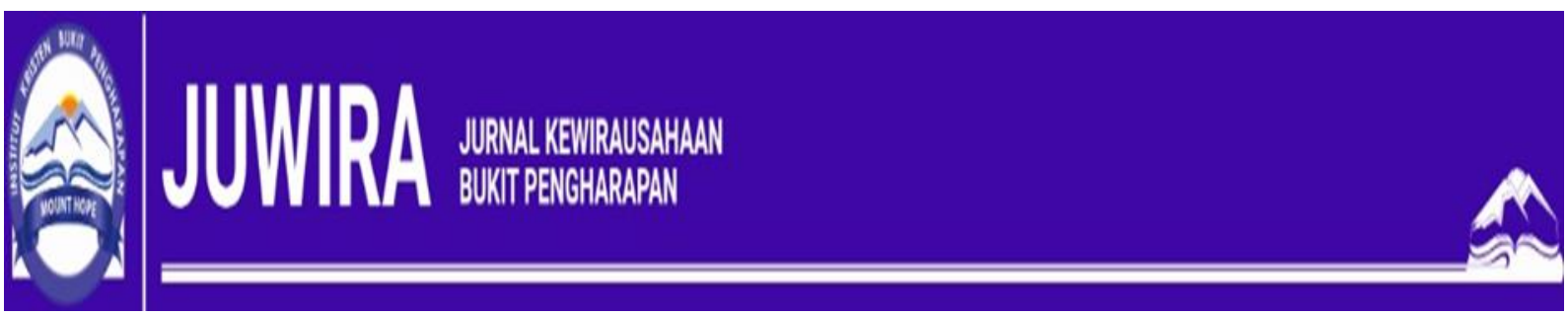

terhadap pengajuan hipotesis yang menyatakan testimonial berpengaruh signifikan terhadap ketertarikan konsumen. Artinya, hasil pada penelitian ini membuktikan tidak adanya pengaruh yang signifikan dari variabel testimonial terhadap ketertatikan konsumen pada produk MS GLOW di Kabupaten Lumajang.

c. Word of mouth berpengaruh signifikan terhadap ketertarikan konsumen pada produk MS GLOW di Kabupaten Lumajang. Hasil ini memberikan dukungan terhadap pengajuan hipotesis yang menyatakan word of mouth berpengaruh signifikan terhadap ketertarikan konsumen. Artinya, hasil pada penelitian ini membuktikan adanya pengaruh yang signifikan dari variabel word of mouth terhadap ketertatikan konsumen pada produk MS GLOW di Kabupaten Lumajang.

\section{DAFTAR PUSTAKA}

Ardiansyah, Widiana, M. E., \& Pudjowati, J. (2014). Pengaruh Testimoni Selegram Dan Gambar Produk Fashion Terhadap Impulse Buying Konsumen Pada Media Sosial Instagram. Jurnal Manajemen Branchmarck, 4(1), 86-96.

Finanda, I. R., \& Wiwaha, A. (2017). Pengaruh Word Of Mouth Dan Brand Image Terhadap Keputusan Penggunaan Salon Kecantikan Pada Konsumen Mil Off Beauty Bar. Jurnal Ilmiah Widya Ekonomika, 1(2), 134-140.

Kuncoro, A., \& A.W., S. (2019). Pengaruh Brand Ambassador, Minat Beli , Dan Testimoni (Studi Pada Situs Jual Beli Online Shopee Indonesia di Universitas Budi Luhur Periode Februari -April 2018). Jurnal Ekonomika Dan Manajemen, 8 (1), 21-34.

Lalitamanik, R., Apriatni, E., \& Dewi, R. S. (2014). Pengaruh Activity, Interest, Opinion (AIO) Dan Persepsi Harga Terhadap Keputusan Menonton Film Di Bioskop E-Plaza Semarang. DIiponegoro Journal Of Social And Political Science, $8(3), 1-10$.

Ningrum, M. S., \& Tresnati, R. (2017). Pengaruh Iklan Testimoni Terhadap Keputusan Pembelian ( Survey Pelanggan Klinik Vanela Beauty Care Cimareme Padalarang ). Prosiding Manajemen, 274-279.

Nst, muhammad fakhru rizky, \& Yasin, H. (2014). Pengaruh Promosi Dan Harga Terhadap Minat Beli Perumahan Obama PT. Nailah Adi Kurnia Sei Mencirim Medan. Jurnal Manajemen \& Bisnis, 14(02), 135-143.

Priansa, D. J. (2017a). Komunikasi Pemasaran Terpadu Pada Era Media Sosial. Bandung: CV. Pustaka Setia. 
Priansa, D. J. (2017b). Perilaku Konsumen Dalam Persaingan Bisnis Kontemporer. Bandung: Alfabeta.

Runtunuwu, J., Oroh, S., \& Taroreh, R. (2014). Pengaruh Kualitas Produk, Harga, Dan Kualitas Pelayanan Terhadap Kepuasan Pengguna Cafe Dan Resto Cabana Manado. Jurnal Riset Ekonomi, Manajemen, Bisnis Dan Akuntansi, 2(3), 18031813.

Sugiyono. (2015a). Metode Penelitian \& Pengembangan Research and Development. Bandung: Alfabeta.

Syifa, A., Heryanto, B., \& Rochani, S. (2018). Pengaruh Testimonial Dan Electroic Word Of Mouth (eWOM) Terhadap Purchase Intention (Studi Pada Toko Online Shop LA Florist ). JIMEK-1(1), 19-33. 